LOFT TECHNICAL REPORT LTR 1310-25

RE \& C REPORT NUMBER RE-A-77-155

MARCH 24, 1978

EGG/LTR--1310-25

DE85 015474

\title{
SEISMIC ANALYSIS OF THE LOFT DIESEL \\ GENERATOR "A" COOLING SYSTEM
}

D. P. Finicle

\section{DISCLAIMER}

This report was prepared as an account of work sponsored by an agency of the United States Government. Neither the United States Government nor any agency thereof, nor any of their employees, makes any warranty, express or implied, or assumes any legal liability or responsibility for the accuracy, completeness, or usefulness of any information, apparatus, product, or process disclosed, or represents that its use would not infringe privately owned rights. Reference herein to any specific commercial product, process, or service by trade name, trademark, manufacturer, or otherwise does not necessarily constitute or imply its endorsement, recommendation, or favoring by the United States Government or any agency thereof. The views and opinions of authors expressed herein do not necessarily state or reflect those of the United States Government or any agency thereof.
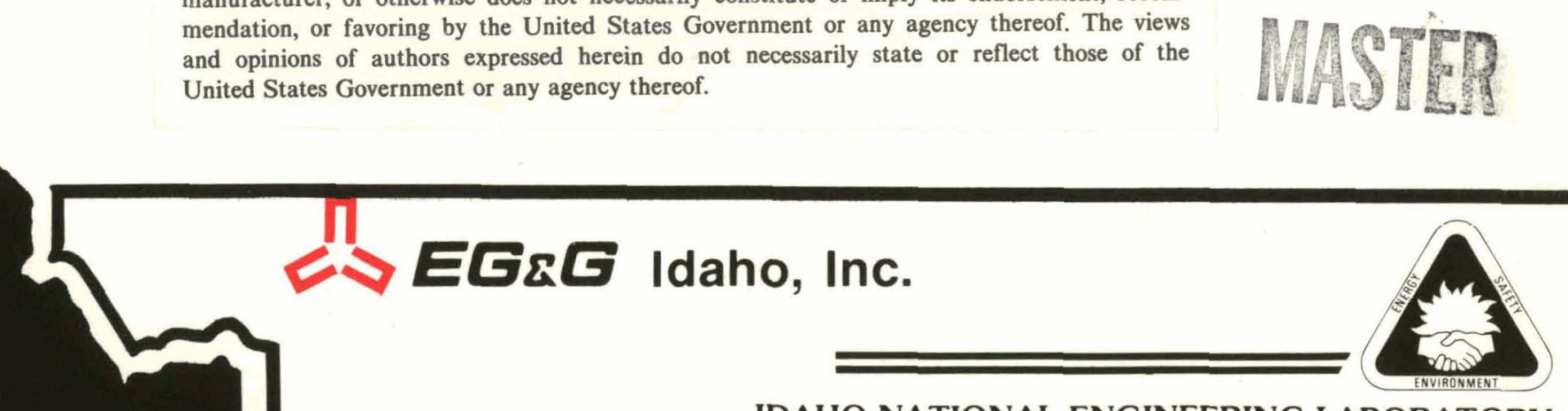

IDAHO NATIONAL ENGINEERING LABORATORY

\section{DEPARTMENT OF ENERGY}




\section{DISCLAIMER}

This report was prepared as an account of work sponsored by an agency of the United States Government. Neither the United States Government nor any agency Thereof, nor any of their employees, makes any warranty, express or implied, or assumes any legal liability or responsibility for the accuracy, completeness, or usefulness of any information, apparatus, product, or process disclosed, or represents that its use would not infringe privately owned rights. Reference herein to any specific commercial product, process, or service by trade name, trademark, manufacturer, or otherwise does not necessarily constitute or imply its endorsement, recommendation, or favoring by the United States Government or any agency thereof. The views and opinions of authors expressed herein do not necessarily state or reflect those of the United States Government or any agency thereof. 


\section{DISCLAIMER}

Portions of this document may be illegible in electronic image products. Images are produced from the best available original document. 


\title{
RESEARCH, ENGINEERING AND CONSTRUCTION REPORT ENGINEERING ANALYSIS DIVISION
}

\author{
APPLIED MECHANICS BRANCH
}

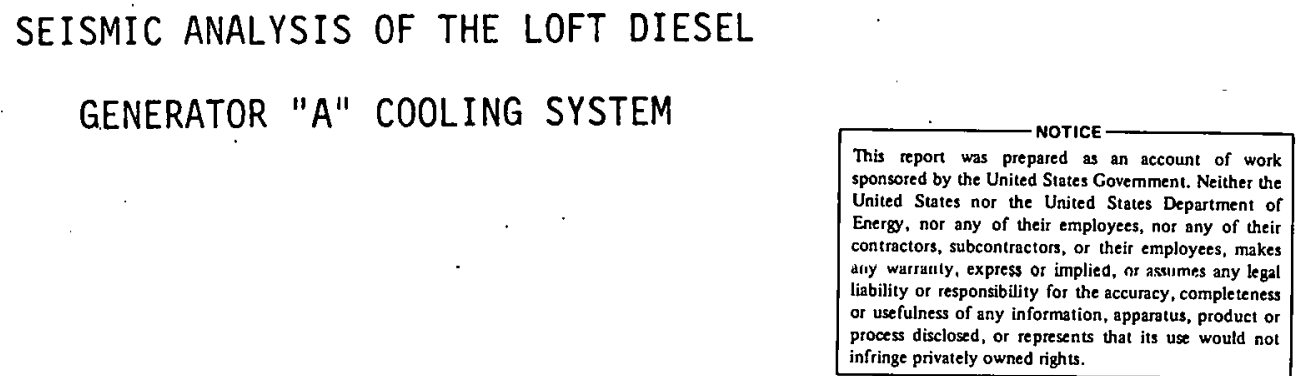

$\frac{\text { D.P. Finicle/ } Q \text {. P. Finucle }}{\text { AUTHOR }}$

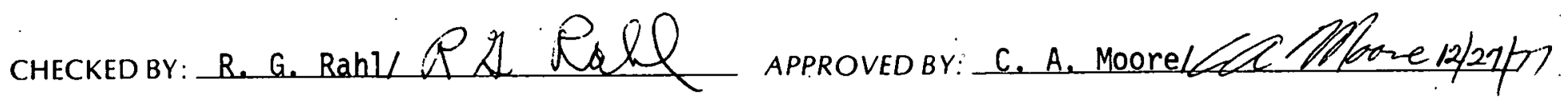
DISTRIBUTICA OF THIS DOCUMENT IS UNLIMITED $q^{\left(\lambda^{\nu}\right.}$ 


\begin{tabular}{l|c||c}
\hline \hline IITLE & $\begin{array}{c}\text { SEISMIC ANALYSIS OF THE LOFT DIESEL } \\
\text { GENERATOR "A" COOLING SYSTEM }\end{array}$ & $\begin{array}{c}\text { REPOT NO. } \\
\text { LTR } 1310-25\end{array}$ \\
\hline & RE-A-77-155 \\
\hline \hline
\end{tabular}

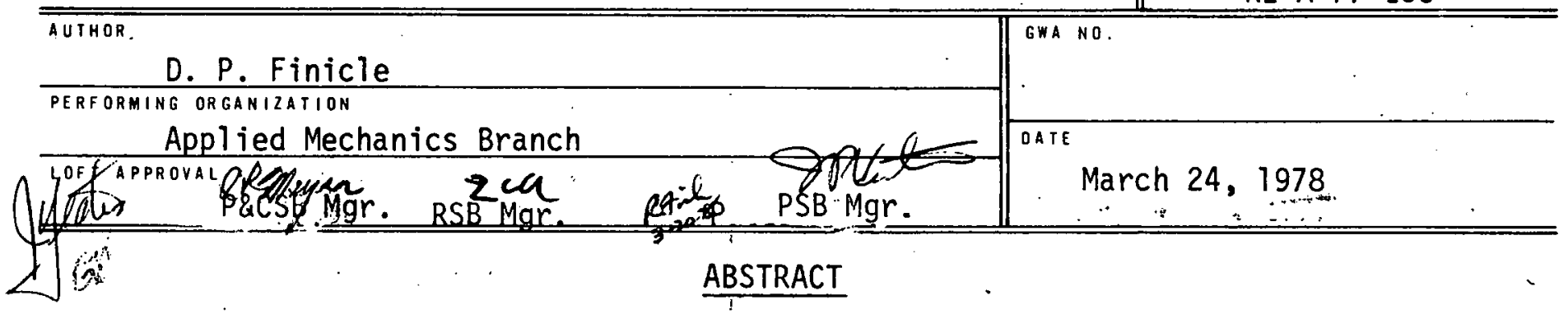

The Diesel Generator "A" Cooling System has been analyzed for a Safe Shutdown Earthquake (SSE). A static equivalent seismic analysis was performed in accordance with RDT F9-2T, Ref. 1. The cooling system was found to be structurally adequate. 
CONTENTS

ABSTRACT .............................. $i$. .

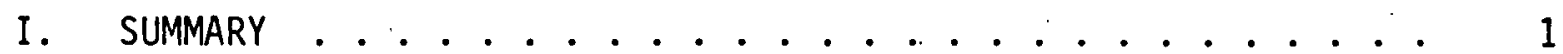

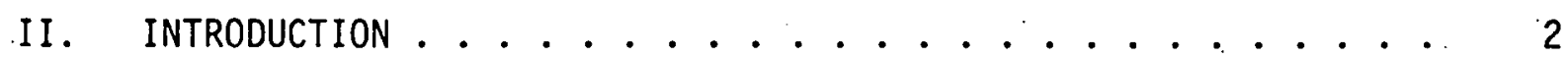

III. DESCRIPTION OF SYSTEM ...................... 3

IV. LOADING ...................... 6

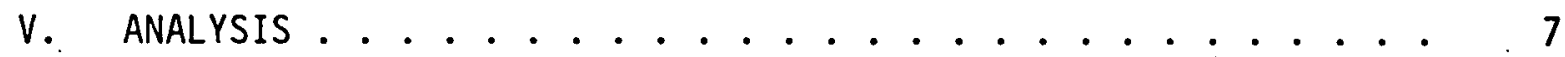

VI. RESULTS ................... 8

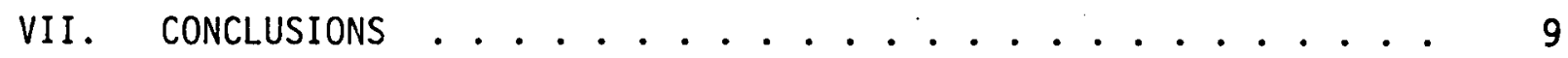

VIII. REFERENCES ........................ 10

APPENDIX A -- SEISMIC ANALYSIS OF THE DIESEL GENERATOR "A" COOLING

SYSTEM .......................

FIGURES

1. Diesel Generator "A" Cooling System . . . . . . . . . . . 4

2. Over Pressure Tank Details ............. 5 
SEISMIC ANALYSIS OF THE LOFT DIESEL.

GENERATOR "A" COOLING SYSTEM

\section{SUMMARY}

A static equivalent seismic analys is of the Diesel Generator " $A$ " Cooling System has been completed. The static equivalent loads were applied to the radiator, over-pressure tank, piping, and the pipe supports. The cooling system was found to be structurally adequate for the applied SSE loading. 


\section{INTRODUCTION}

The diesel generator " $A$ " is located in the Hanger at the LOFT Facility. The cooling system is a closed loop system, and the coolant is cooled by use of a radiator. Very little information was provided on the LOFT diesel generator "A" cooling system. Most of the values used in the analysis were obtained from field measurements or by assumption. All assumed $\forall a l$ ues were selected to produce conservative results. 


\section{DESCRIPTION OF SYSTEM}

The diesel generator "A" is located in the Hanger at the LOFT Facility. Its purpose is to provide electrical power during a power outage. The diesel generator " $A$ " consists of a diesel engine connected to an electrical generator. The coolant for the diesel engine is provided by a closed loop system which contains a radiator. The radiator and the engine are connected by a set of pipes. A sketch of this system is shown in Figures 1 and 2. 
\#- Numbers used to Identify Lines

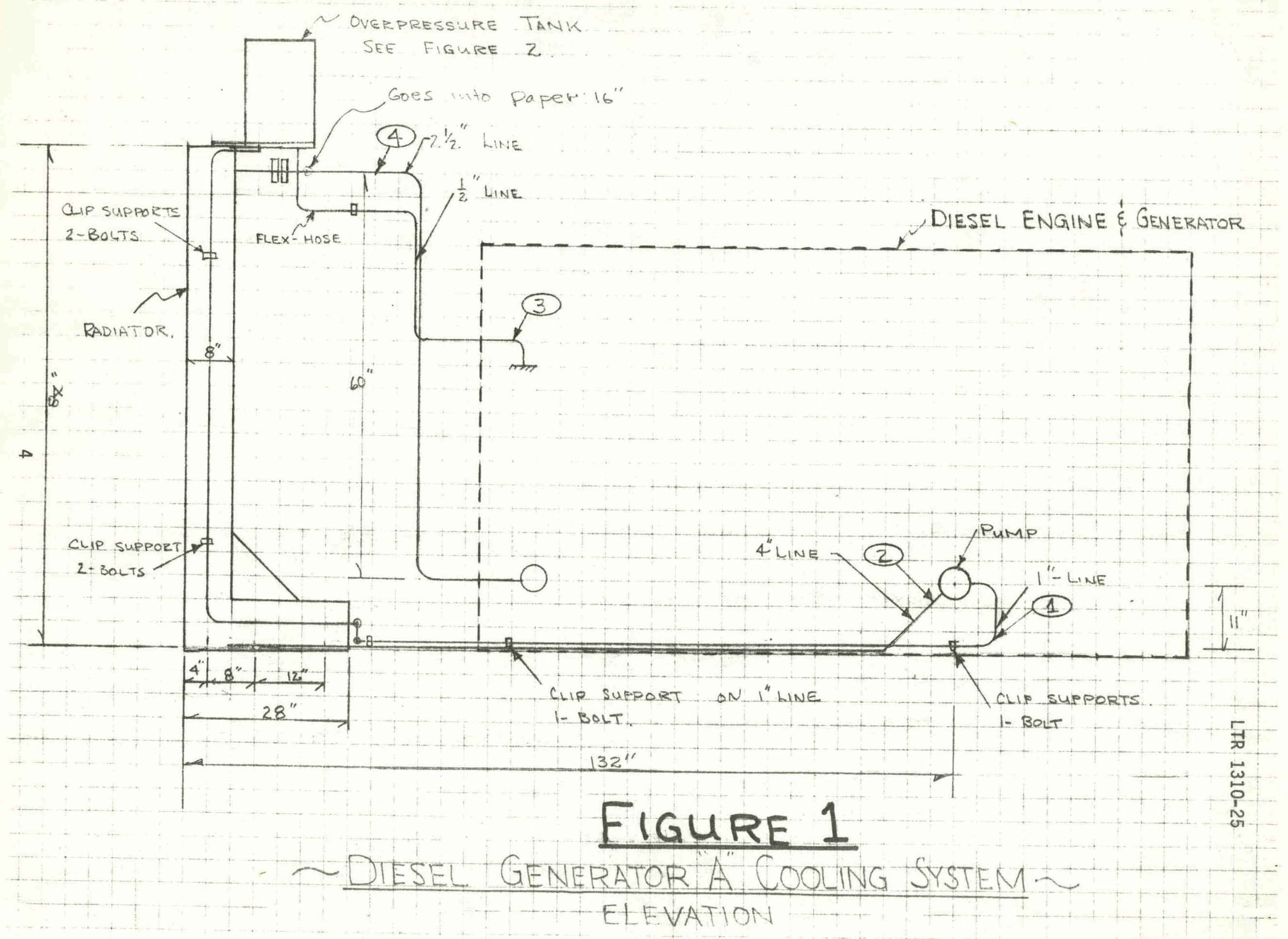



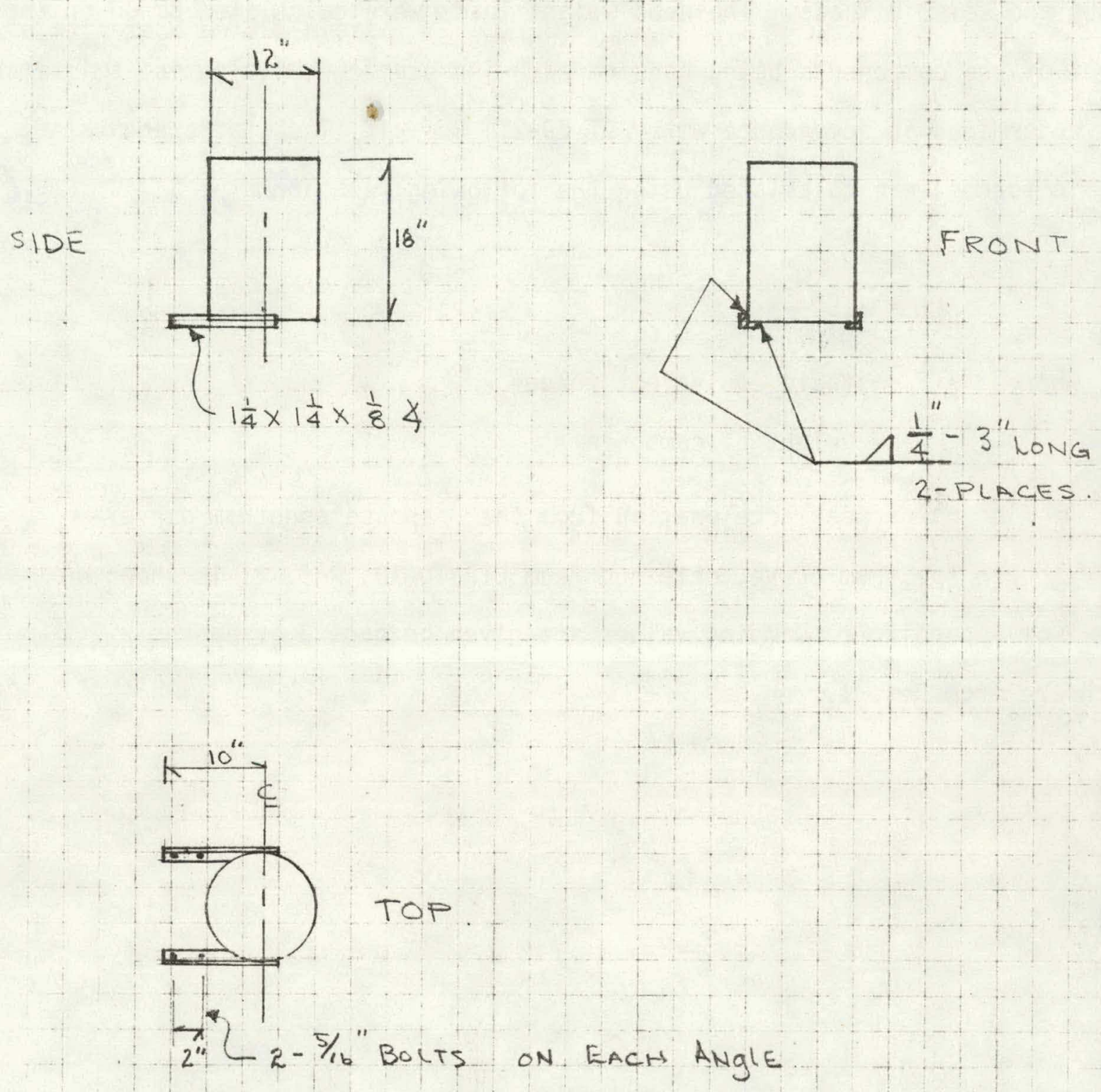

- QVER PRESSURE TANK DETAILS -

FIGURE 2 


\section{LOADING}

The only load combination considered in this analysis is the sum of dead weight and seismic loads. The dead weight loads were calculated based on the weight of the components being considered. The static equivalent seismic loads were determined in accordance with RDT F9-2T, Ref. 1 . The static equivalent seismic forces were calculated using the following relationship:

$$
\text { where } \quad \begin{aligned}
F & =1.5 \frac{W_{e}}{g} A \\
W_{e} & =\text { static equivalent force } \\
A & =\text { peak acceleration from the response spectrum curve. }
\end{aligned}
$$

The response spectrum curve, obtained from LTR 10-19, Ref. 2, is shown on page 2 of Appendix A. Damping values are given on page 3 of Appendix A, which are from Ref. 1. 


\section{ANALYSIS}

A simplified static equivalent seismic analysis was done. The radiator and its supports were analyzed like a cantilever beam. The piping lines were analyzed as simply supported beams in order to obtain the maximum possible bending moments. The attachments to the pumps were not analyzed since they were not included in the scope of this job. 


\section{RESULTS}

The entire diesel generator "A" cooling system was found to be structurally adequate to withstand an SSE event. 


\section{CONCLUSIONS}

The static equivalent seismic analysis of the deisel generator " $A$ " cooling system has been completed. Conservative analytical techniques and loading were used in the analysis. No problem areas were found with the cooling system. 


\section{REFERENCES}

1. RDT Standard F9-2T, "Seismic Requirements for Nuclear Design of Nuclear Power Plants and Test Facilities" (January 1974).

2. V. W. Gorman and R. C. Guenzler, "LOFT SSE Definition and Seismic Analysis Methods", LOFT Technical Report LTR 10-19 (October 8, 1974). 
IDAHO NATIONAL ENGINEERING LABORATORY

FORM INEL-1592

(Rev, 4-76)

CALCULATION WORK SHEET

ITR1310 25

PAgE $A 1$ OF PAGES

suBJEct DiESEL GENERATOR "A" COOLING SYSTEM DATE palpated or li. F. Fllwigle CHeCKED

WORK REQUEST

SEISMIC ANALYSIS OF THE DIESEL GENERATOR "A" COOLING SYS,

A static equivalent seismic analysis of the LOFT Diesel Generator. Cooling System will be performed. Static Equivalent Loads will be determined based on. The following two formula's from RDTF9-2T, ref 1 :

$$
F_{E Q}=1.5 \frac{W_{6}}{g} A_{5}
$$

$$
F_{E Q}=8.0 \frac{W_{e}}{g} A_{S}
$$

where spectra is available for the support point

on.

where response spectra is not available for the support point.

The Accelleration values obtained from: the response spectrum ave from LTR 10-19, ref. 2 . This is shown. an pg 2 .

The appropriate danging: values are obtained from RDT Fg-2T, ref. 1. These values are shown on page. 3 . 
PAgE $A z$ OF pages

SUBAECT

premared or D P Finucle

CMEckero

onte

WORK REOUEST

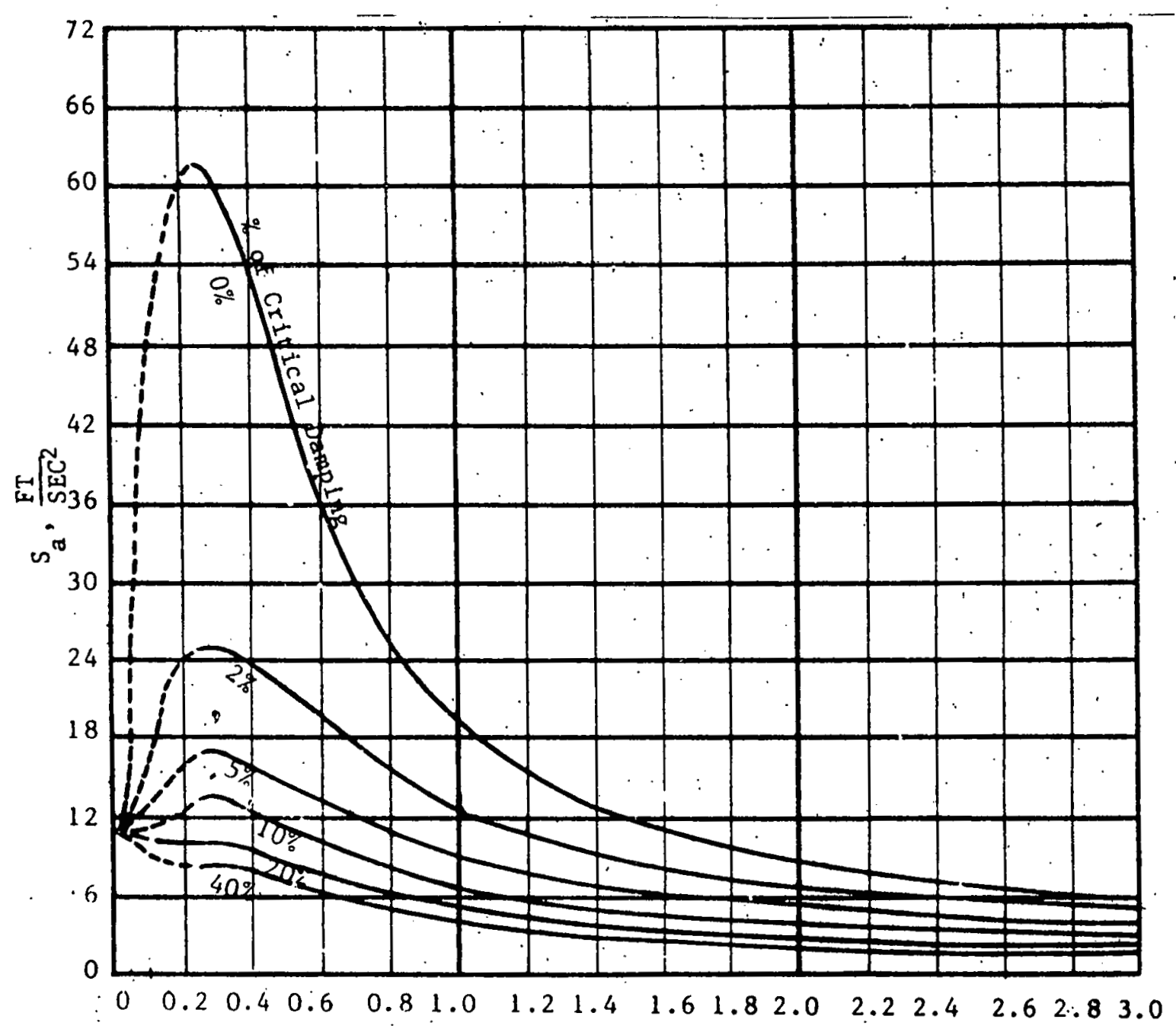

Pertod of Vtbration, $T$, sec.

〜 RESPONSE SPECTFRM CURVES: 


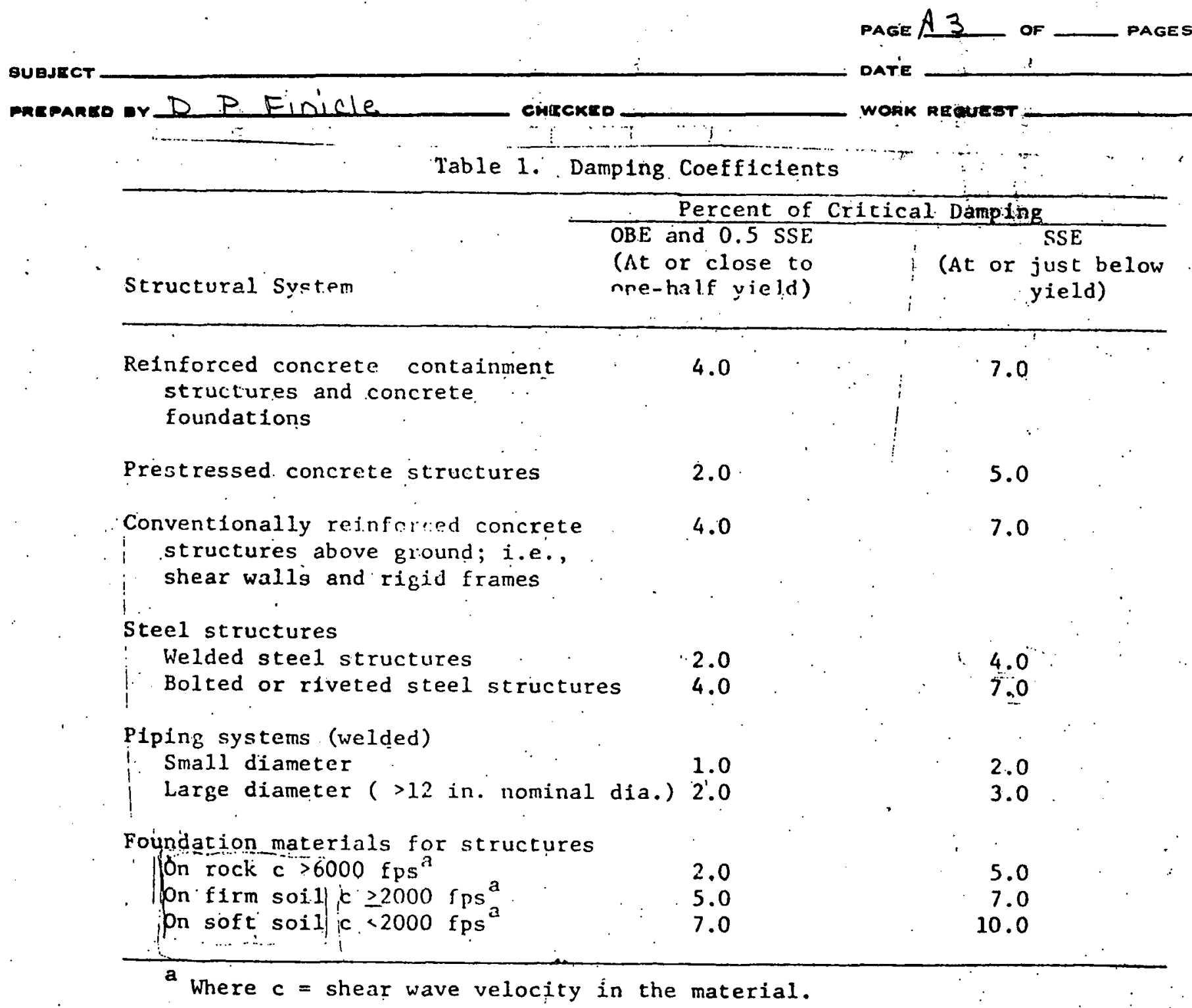

The diesel genevatow A"colung system. is a closed. hoop Cooling. System. Thas Vital Power Gcriegator is located in the Airplane HANGER.

As far as cond bs determined, the coolung systecun is uct showing on the duawings that were provided. Sketches weve made dining a recent trip to the site and these sketches will be used to analyze the cooling systrein. 
FORM INEL-1592

(Rev. 4-76)
IDAHO NATIONAL ENGINEERING LABORATORY

CALCULATION WORK SHEET

TR 1310

25

PAGE

or

PAGES

DATE

WORK REQUEST

curckeso

The details on the. Radiation were obtained From Young Radiator in ... Racine Wisc. A... Mr. Marc EAMan was -contacted and he gave the weight of the radiator (dry) as 200010 and the : C.G... as being 5.4.5" from the top and 29.5". from the left side. The capacity of the radiator was given as. 40 gal.

Analyze The radiator supports

The radiator is shown in fig l. it is encased in an 8." Channel Section. The radiator is 6 ' wide.

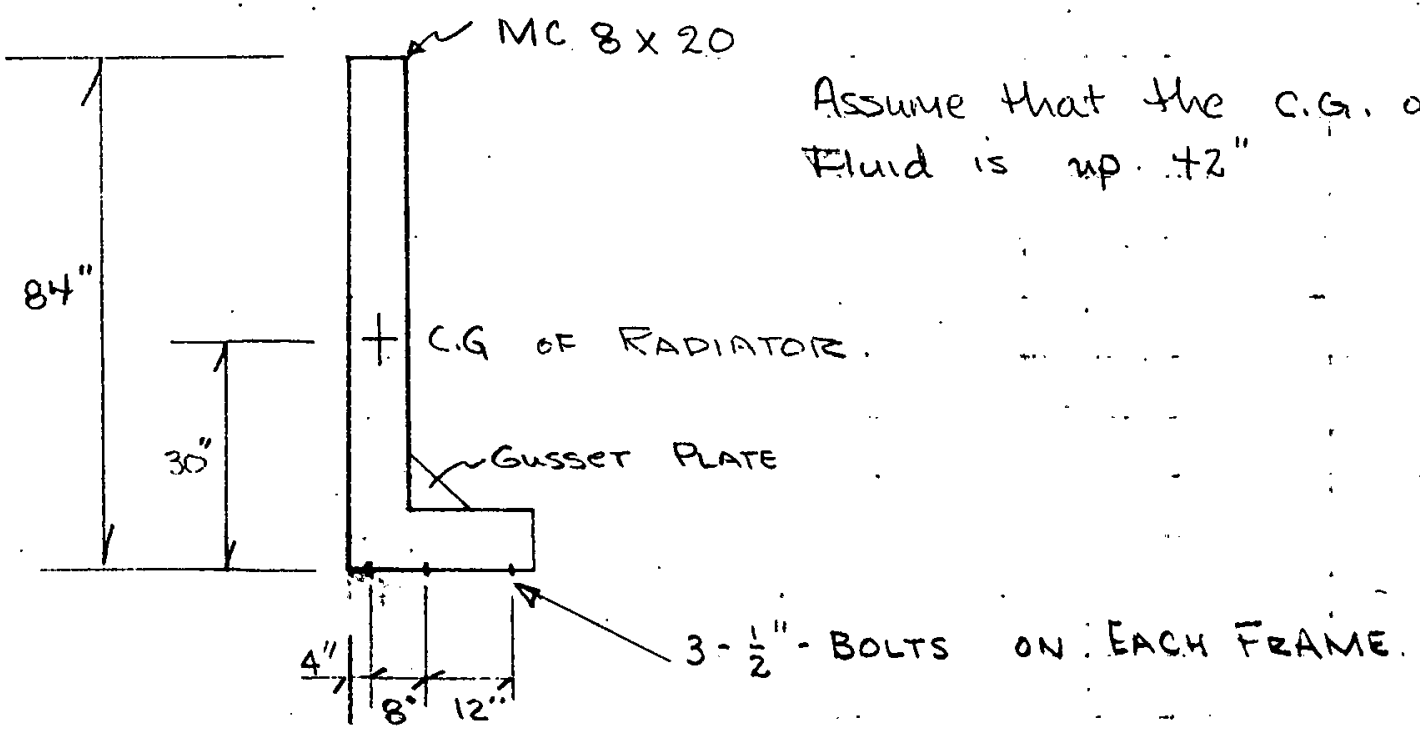

frompg 3, the appropriate damping value is 790 for an SSE. from pg 2 , the peak accellevation. is is $\mathrm{ft} / \mathrm{sec}^{2}$. 
IDAHO NATIONAL ENGINEERING LABORATORY

FORM INEL-1592
(Rev. 4-76)

CALCULATION WORK SHEET

LTR 1310 25

page $\$ 5$ PAGES DAte

prepanto or P Fin isle

eniscke WORK REQUest

$$
F_{E Q}=1.5 \frac{W_{e}}{9} A_{S}=\frac{1.5 W}{3212} \times 15=70 \mathrm{~W}=\text { HORIZONTAL }
$$

$$
F_{E Q \text { VERT }}=\frac{2}{3}(.70 W)=.47 \mathrm{~W}
$$

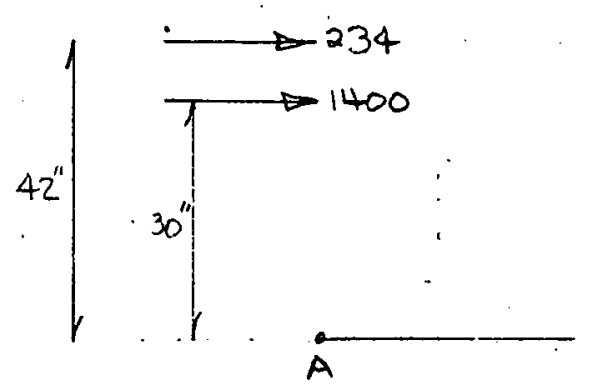

$$
W_{\text {RAD }}=200016
$$$$
\text { F vert }=933 \mathrm{lb}
$$$$
W_{\text {fin }}=8.34 \frac{\mathrm{lg}}{\mathrm{gal}} \times 40=33.41 \mathrm{lb} \text {. }
$$

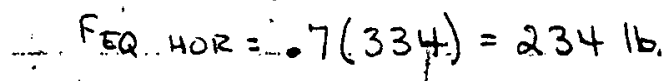$$
\text { EVERT }=156.16
$$

- Ma BASE of RADiATOR $=30(1400)+42(234)=51828 " \#$

$$
M / \text { Bolt pattern = } 259.14 \text { "\#. }
$$

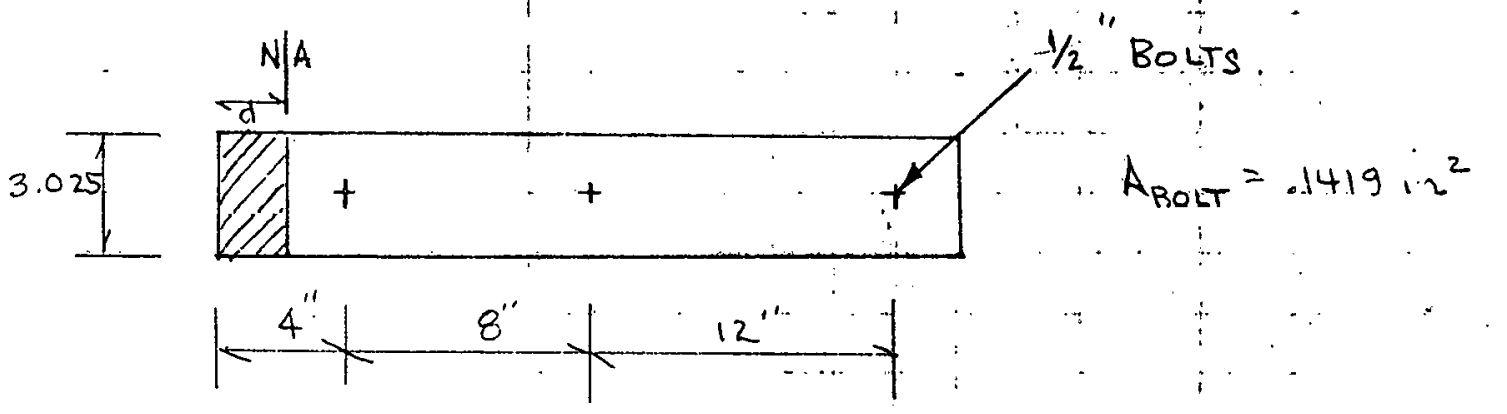

Assume $d=2^{\prime \prime}$

Equate Moments of the AReas

$$
\begin{aligned}
2(3.025) 1 & =.14 .19[2+10+22] \\
6.05 & =4.54 \mathrm{nn}^{3}
\end{aligned}
$$

try $d=1$ i.

$$
\begin{aligned}
\frac{\operatorname{lin}^{2}(3.025)}{2} & =149[2.25+10.25+120.25] \\
4.633 & =4.93, \mathrm{in}^{3} \quad \text { CLOSE. ENOW OH. }
\end{aligned}
$$


FORM INEL-1592

(Rev. 4-76)
IDAHO NATIONAL ENGINEERING LABORATORY

CALCULATION WORK SHEET

LTR1310:25

PAGE $\triangle 6$ OF

PAGES DATE WORK REQUEST T checks

perenco ar $P$ F N

$$
\begin{gathered}
I_{\text {BOLT PATTERN }}=\frac{3.025(1.75)^{3}}{3}+.1419\left(2.25^{2} \ldots+10.25^{2}+22.25^{2}\right) \\
5.04+85.9=91.30 \mathrm{in}^{4}
\end{gathered}
$$

Stress in the Bouts

$$
\begin{aligned}
& J_{\text {TEN SOLE }}=\frac{M_{C}}{I}=\frac{25914(22.5)}{91.3}=6386 \mathrm{psi} \\
& \tau=\frac{(1400+234)}{3(.1419)}=3840 \mathrm{psi} .
\end{aligned}
$$

The Bolt stresses are ftelatioely low j Any BolT MatERIAL WoUlD BE OK.

CHECK "G" LOADING IN THE OTHER DIRECTION

$$
M=51.828 .
$$

The moment is resisted by a couple acting at $7 z^{\prime \prime}$

$$
\begin{aligned}
& \text { Force/BOLT PATtERn }=\frac{51828}{.72}=719 \mathrm{lb} / \mathrm{BOLT} \text { PAT. } \\
& \text { ForCE/BOLT }=719 / 3=239 \mathrm{lb} / \mathrm{BOLT} \\
& \sigma_{T}=239 / 1419=1690 \mathrm{ps} \text {. }
\end{aligned}
$$

Stresses how.

$\therefore$ Support For The Radiator is Adequate 
FORM INEL-1592
(Rev. 4-76)

IDAHO NATIONAL ENGINEERING LABORATORY

CALCULATION WORK SHEET

ITR1310 ?

PAge 17

or

PAGES

SUBJECT DATE

PREPAREd BY $O$ P FUnicle

CHсCKео

WORK REQUEST

ANALYZE THE OVERPRESSURE TANK SUPPORTS

(see figs $1 \dot{\varepsilon} z$ )

The over pressure tank is shown sitting on top of the radiator in fig. 1: The details for the supports are. shown on fig. 2 .

Per. Gary Hegewhorst of hort, This tank will never be over 1/4. Full. This would put the fluid level at $18 / 4=4.5$ "deep.

Wt of tank.

Assunie 3/8 "Thick Wall.

$$
\begin{aligned}
\text { VOL. STEEL } & =\pi 12\left(\frac{3}{8}\right) 18+\frac{\pi}{4}(12)^{2} \frac{3}{8}= \\
& =254+42=297 \text { in }^{3}
\end{aligned}
$$

WT. TANK $=.284 \mathrm{lb} / \mathrm{m}(29.7) \cong .85 \mathrm{lb}$.

WT. WATER $=\frac{\pi / 4(12)^{2} 45}{1728}(62.4)=18.4 \mathrm{lb}$

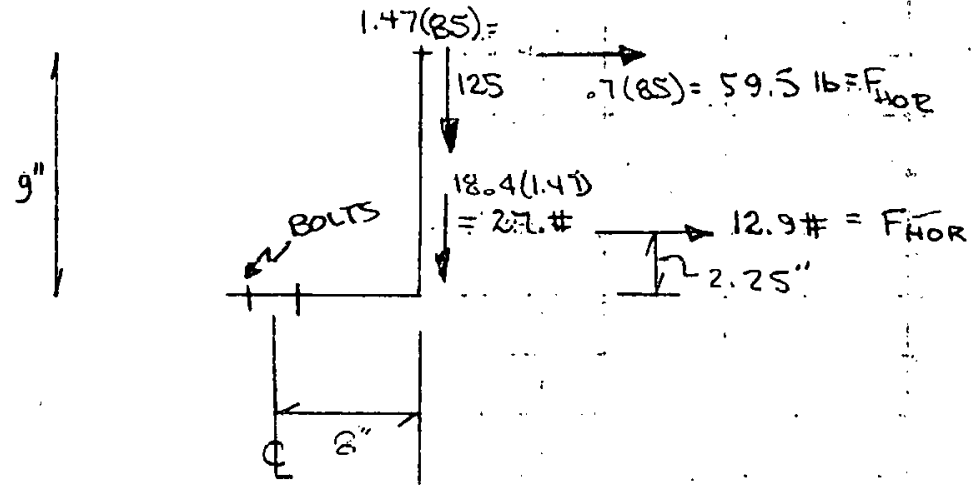

$$
\begin{gathered}
M_{L_{\text {OF BOLTS }}}=3[(125)+27]+9(59.5)+2.2 .5(12.9) . \\
M_{q}=1780 \%
\end{gathered}
$$


FOAM INEL-1582

IDAHO NATIONAL ENGINEERING LABORATORY

(Rev. 4-76)
LIR 1310

25

page 18

or

PAges

ButuT CT DATE

mapanzo ar DP Fin isle ceres WORK REQUEST

$$
\text { M/BOLT PATTERN }=1780 / 2=890 . " \#
$$

This MOMENT is RESISTED BY A COUPLE

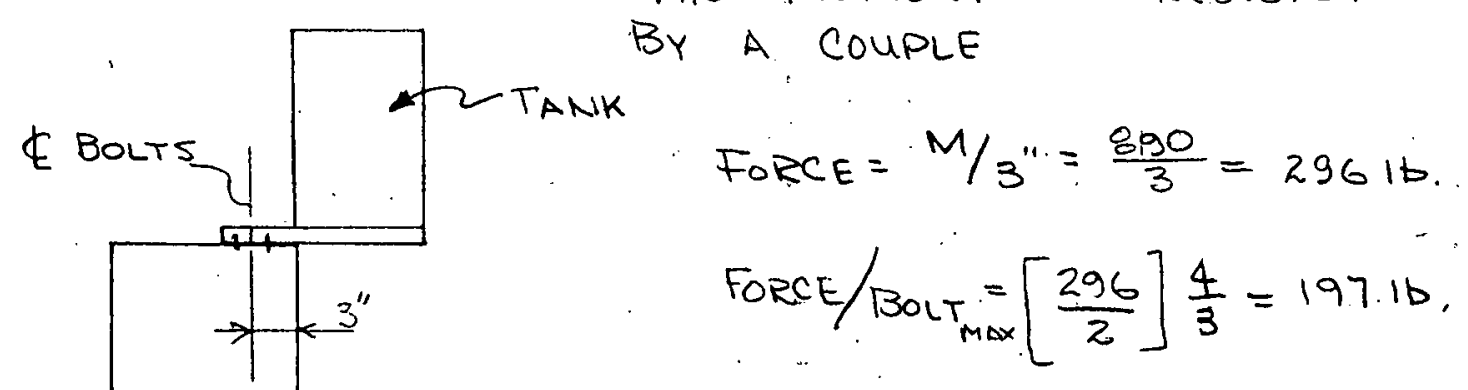

Bolt stresses.

Tensile Area $=.0524 \mathrm{in}^{2}$ $5 / 16$ " BoLTS.

$$
\sigma_{\text {TENSILE }}=\frac{197}{.0524}=3759 \mathrm{psi}
$$

$\therefore$ Bolt Stresses Ave how

Check Bending in the $y$ Sections.

$$
\begin{aligned}
& 1 \frac{1}{4} \times 1 \frac{1}{4} \times \frac{1}{8} \quad x \\
& A=, 297 \mathrm{in}^{2} \\
& S_{X X}=.049 \mathrm{in}^{3} \\
& \sigma_{\text {BENDING }}=\frac{890}{.049}=18163 \mathrm{psi} .
\end{aligned}
$$

Assuming $A-36$ stael

$$
\begin{aligned}
& f_{y}=36000 \text { psi }>18163 \\
& \therefore \not-\text { Sections ave ok }
\end{aligned}
$$


IDAHO NATIONAL ENGINEERING LABORATORY

FORM INEL-1592

(Rev. 4-76)

CALCULATION WORK SHEET

ITR1310 25

PAge A 9 OF PAGES DATE WORK REQUEST

The welds are or By Inspection

$\therefore$ The overpressure - Tank Supports Are Adequate

Anaizize The Piping \& Supporters (See figure 1)

From PG. 3, the appropriate damping value for piping is $2 \%$ of Critical. DAmping.

From pg. 2, the peak accelleration: $=25.5 \mathrm{ft} / \mathrm{sec}^{2}$ This will que static equivalent seismic loading

$$
\begin{aligned}
& F_{E Q_{\text {HOR. }}}=1.5 \mathrm{As}^{\prime} \frac{\mathrm{W}}{\mathrm{g}}=\frac{1.5(25.5)}{32.2} \mathrm{~W}=1.19 \mathrm{~W} \\
& F_{E Q_{V E R T}}=\frac{2}{3}(1.19 \mathrm{~W})=279 \mathrm{~W}
\end{aligned}
$$

Analyze the 1" Line $D$ see fig I

the longest span on this line is about 75 inches Assume Sch! to Pipe

$$
\begin{aligned}
& W_{\text {PIPe }}=1.678 \mathrm{lb} / \mathrm{ft} \quad S_{\text {PIPE }}=.1328 \\
& W_{\text {WATER }}=.375 \mathrm{lb} / \mathrm{ft} . \\
& \Sigma W=2.053 \mathrm{lb} / \mathrm{ft}=.171 \mathrm{16} / \text { inch } .
\end{aligned}
$$

Assuming a Simply Simpperted Span 75" Long.

$$
\begin{gathered}
(1+.79) \mathrm{W} \\
1.79 \mathrm{~W} W \text { RESULTANT }=2.15 \mathrm{~W}
\end{gathered}
$$


IDAHO NATIONAL ENGINEERING LABORATORY?

CALCULATION WORK SHEET

s.

$\operatorname{irb130\% 5}$

FORM INEL-1592

PAGE ADO OF PAGES

SUBJECT DATE

$$
\begin{aligned}
& \text { preparto ir } D \rho \text { Findele } \\
& \text { enzerrib } \\
& \text { WÓR ReQUESt }
\end{aligned}
$$

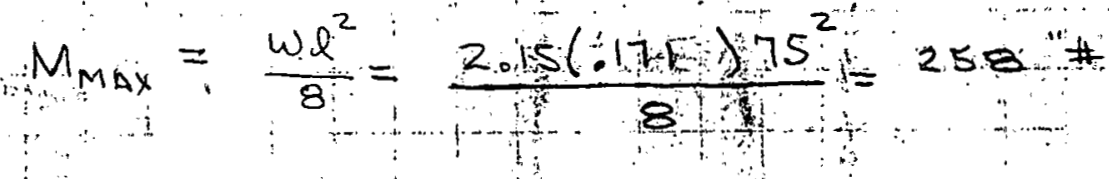

$$
\begin{aligned}
& J_{B E N D I N G}=\frac{M}{5}=\frac{258}{1328} \cdots \underbrace{250}
\end{aligned}
$$

Check stresses in the 4" Line (2) Sec fig. 1

The length of this lime is $\approx 124$

Assuming schedule 40 pip el .... $S=3.214$

$$
\begin{aligned}
& W_{\text {pipe }}=10.79 .16 / \mathrm{ft} \\
& W_{\text {WATER }}=5.50 .11 \mathrm{det} \\
& \sum W=16.29 \mathrm{lb} / \mathrm{st}=1.36 \mathrm{~b} / \mathrm{in} \\
& M_{\max }=\frac{W e^{2}}{8}=\frac{215(1.3 .6) 124^{2}}{8}=560^{\prime \prime} \\
& \sigma_{\text {bendivi }}=\frac{M}{5}=\frac{5610}{3.214}=1750 \text { psi }
\end{aligned}
$$

Check, stizesses in the $1 / 2$ " line

The unsupported length of this line $\approx 50$ ". Assume Sch. 40 Pipe:

$$
\begin{aligned}
& W_{p}=.850 \mathrm{lb} / \mathrm{ft} \quad S=.04069 \mathrm{in}^{3} \\
& W_{w}=.132 \mathrm{lb} / \mathrm{ft} \\
& \sum W_{t}=.09816 / f t=10.0817 \mathrm{lb} / \mathrm{in} .
\end{aligned}
$$

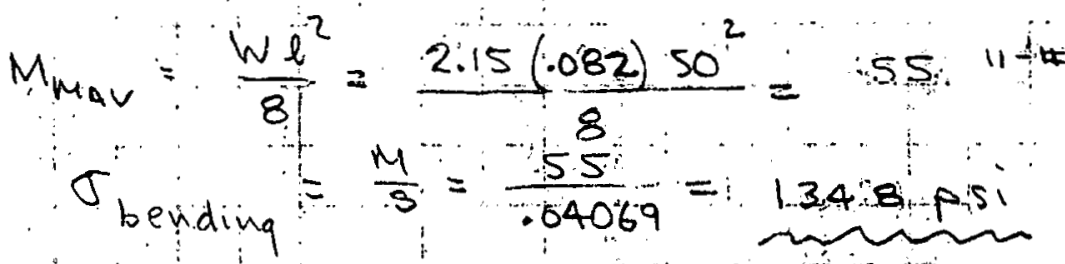




\section{APPENDIX A}

SEISMIC ANALYSIS OF THE DIESEL

GENERATOR "A". COOLING SYSTEM 
IDAHO NATIONAL ENGINEERING LABORATORY

CALCULATION WORK SHEET
FOAM INEL-1592

hov. 4-76)

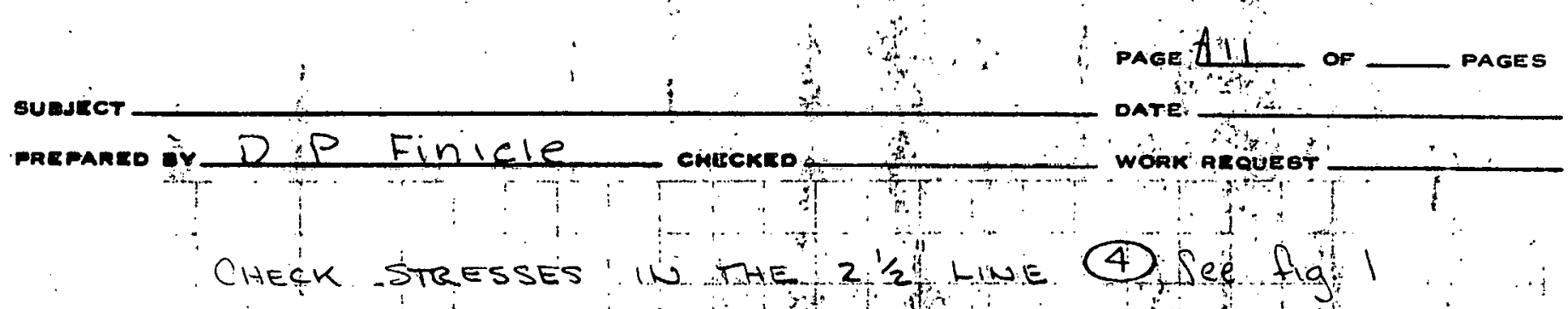

$\operatorname{Tr} 131025$

,

This line is :135" long

Assume Sch 40

$$
S=1.0,64
$$

$$
\begin{aligned}
& W_{p}=-5 \cdot \cdot \cdot 9: 1 / f t \\
& W_{W}=207 \% / f+
\end{aligned}
$$

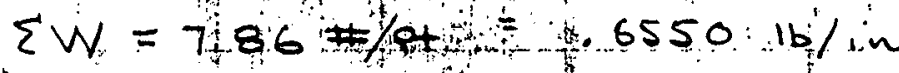

$$
\begin{aligned}
& M_{\text {Mar }}=\frac{w l^{2}}{8}+\frac{6550(135)}{40}(2.15)=3208 \% \\
& \sigma_{\text {bending }}=\frac{3208}{1.064}=3016 \text { psi }
\end{aligned}
$$

'As: can be seen, the stresses in the pipes are... all query tow a. $\therefore$. The. Piping is. structurally Adequate

check the supports

0

The only supports that exist ave the clip supports on the 1 " Line (D. The weakest of these supports would be the ones with only ope bolt.. The bolts " fave 3/8." Din."

The Tensile Stress Area is ot hs on

The max imam load/fcip an id load/Boir $=\frac{21 l}{2}$... From fig

$$
\frac{2.15(.171) 75}{2}=1416 \frac{10 K B y}{10}
$$


FOAM INEL-158́2

(Rev. 4-76)
IDAHO NATIONAL ENGINEERING LABORATORY

CALCULATION WORK SHEET

LTR1310?5

PAGE $\mathbb{A} \backslash Z$ OF PAGES

Date

WORK REQUEST

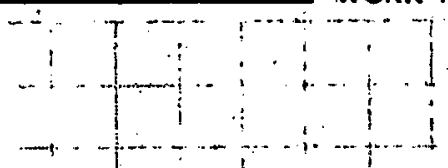

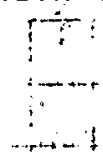

Since ho information is available on the pumps that ave on the Diesel Generator. and these puns ave not inclined - in the scope of Hill is

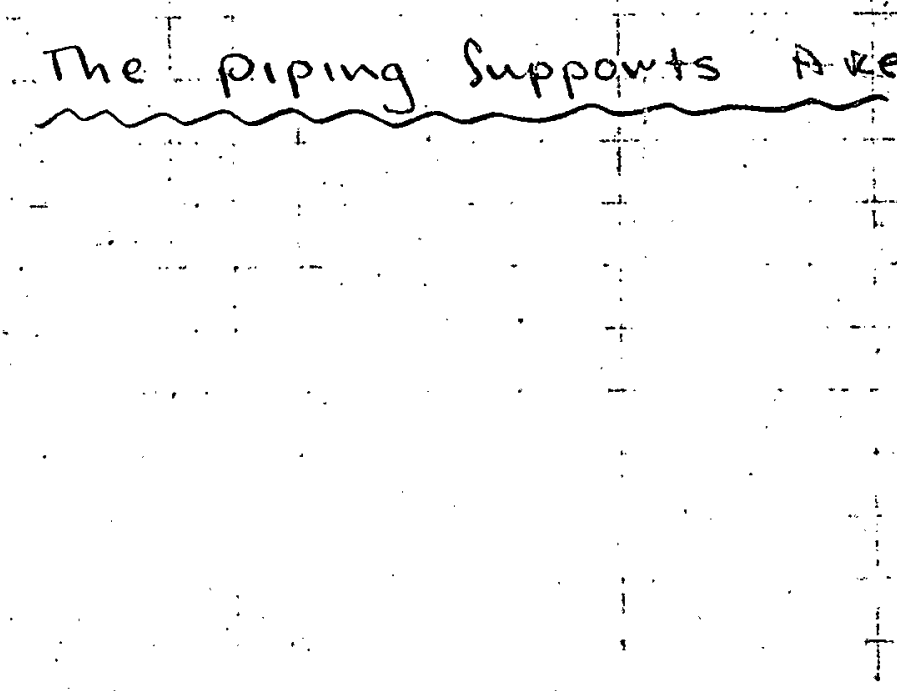

3 


\section{LEGIBILITY NOTICE}

A major purpose of the Technical Information Center is to provide the broadest possible dissemination of information contained in DOE's Research and Development Reports to business, industry, the academic community, and federal, state, and local governments. Non-DOE originated information is also disseminated by the Technical Information Center to support ongoing DOE programs.

Although large portions of this report are not reproducible, it is being made available only in paper copy form to facilitate the availability of those parts of the document which are legible. Copies may be obtained from the National Technical Information Service. Authorized recipients may obtain a copy directly from the Department of Energy's Technical Information Center.

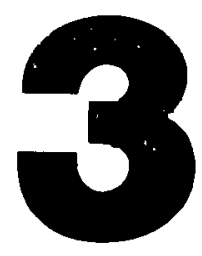

